\title{
PERAN MELANOSIT PADA PROSES UBAN
}

\author{
Roslin Sinaga \\ Sunny Wangko \\ Marie M. Kaseke

\begin{abstract}
Bagian Anatomi Histologi Fakultas Kedookteran Universitas Sam Ratulangi Manado
Email: ochinria7naga@me.com
\end{abstract}

\begin{abstract}
Hair is a long keratinous structure derived from invaginated epidermal epithelial cells. Hair varies in colour, diameter, and distribution, depending on race, age, gender, and regions of the body. Histologically, the structure of hair is formed by three strata, or inter alia: medulla, cortex, and cuticle. Melanocytes of hair follicles are specific cells that play some important roles in the production of hair pigment (melanin). Gray hair appears due to aging. In this case melanocyte activities in melanin production decrease gradually. There are other external factors that can influence the appearance of gray hair e.g smoking and hair dyes; both of them produce hydrogen peroxyde which inflict eumelanogenesis. Eumelanin is the dark-brown melanin, meanwhile feomelanin is the yellow one. An internal factor related to the early appearance of grey hair is a genetically induced one.
\end{abstract}

Keywords: grey hair, melanocyte, hair.

\begin{abstract}
Abstrak: Rambut merupakan struktur panjang berkeratin yang berasal dari invaginasi epitel epidermis. Warna, ukuran dan penyebaran rambut bervariasi sesuai ras, umur, jenis kelamin, dan area tubuh. Rambut terdiri atas tiga lapis sepusat yaitu: medula, korteks, dan kutikula. Melanosit folikel rambut merupakan sel-sel khusus yang secara langsung mengendalikan produksi pigmen rambut, yaitu melanin. Munculnya rambut uban diakibatkan proses penuaan dimana aktivitas sel melanosit juga ikut menurun secara bertahap. Beberapa faktor eksternal yang dapat memicu rambut menjadi uban antara lain merokok atau penggunaan cat rambut, yang merangsang pembentukan hidrogen peroksida sehingga sintesis eumelanin menjadi terganggu. Eumelanin ialah jenis melanin yang berwarna coklat-hitam, sedangkan feomelanin berwarna pirang. Faktor internal lain yang berkaitan dengan tumbuhnya uban lebih awal ialah genetik.
\end{abstract}

Kata kunci: uban, melanosit, rambut.

Rambut kepala ras Asia umumnya berwarna hitam, namun seiring dengan pertambahan usia khususnya pada usia lanjut warna rambut berubah menjadi putih. Pada keadaan normal rambut putih mulai muncul pada usia sekitar 39 tahun. Pada pertambahan usia terjadi penurunan kemampuan melanosit menghasilkan melanin. Faktor genetik juga mempengaruhi perubahan warna rambut menjadi putih pada usia relatif muda. ${ }^{1}$

Rambut adalah struktur berkeratin panjang yang berasal dari invaginasi epitel epidermis. Warna, ukuran dan penyebaran rambut bervariasi sesuai ras, umur, jenis kelamin dan bagian tubuh. ${ }^{2}$ Rambut berfungsi melindungi kulit kepala dari berbagai gesekan atau benturan. ${ }^{3}$

Siklus pertumbuhan rambut memiliki tiga tahap utama, yang dikenal sebagai ta- 
hap anagen (tahap pertumbuhan), tahap telogen (tahap istirahat), dan tahap katagen (periode transisi antara tahap-tahap sebelumnya). ${ }^{4}$

Rambut mempunyai masa pertumbuhan tertentu; untuk rambut kepala kurang lebih 2-4 tahun dan untuk bulu mata 3-4 tahun. Menjelang pertumbuhan berakhir proliferasi sel-sel yang belum berdiferensiasi terhenti. Akar rambut lepas dari matriks dan rambut rontok. Setelah masa istirahat, puntung folikel memasuki masa pertumbuhan dan berhubungan dengan papila lama atau terbentuk papila baru. Setelah itu, rambut baru tumbuh dari folikel yang terbentuk kembali. ${ }^{5}$

Studi yang dilakukan selama dua tahun oleh University Hospital Uppsala di Swedia menemukan bahwa asam folat, vitamin B12, dan paparan sinar matahari bisa membantu mendorong kembali pigmentasi kulit dan rambut. ${ }^{6}$ Terdapat dua macam pigmen rambut yaitu eumelanin dan feomelanin. Pigmen eumelanin biasanya terdapat pada orang-orang berkulit hitam, seperti Asia, Arab, dan India, sedangkan pigmen feomelanin berwarna kuning, terdapat pada orang-orang kulit putih dan albino. ${ }^{7,8}$

Penelitian menggunakan tikus dengan melakukan penghambatan jalur sinyal Wnt dari produksi melanosit dalam folikel rambut mendapatkan bahwa pertumbuhan rambut melambat atau berhenti sama sekali. Selain itu, melanosit menghentikan produksi pigmentasi rambut, yang secara efektif menyebabkan tikus untuk mengembangkan folikel rambut abu-abu. ${ }^{9}$ Penelitian lain mengemukakan bahwa faktor genetik berperan dalam jumlah melanosit folikel rambut. Pada penelitian yang dilakukan oleh Harvard Medical School dan University Hokkaido Graduate School of Medicine di Jepang, ditemukan bahwa semakin tua tikus semakin berkurang melanosit, yang merupakan tanda proses penuaan. Penelitian ini juga menunjukkan bahwa genetik berperan dalam proses uban, baik berkaitan dengan jumlah melanin yang diproduksi maupun kekuatan jalur sinyal Wnt. ${ }^{9}$
Penelitian Hegney di New York United Langone Medical Center menemukan peran penting sinyal Wnt yang bertanggung jawab untuk mengendalikan berbagai proses dalam tubuh dan pigmentasi rambut. ${ }^{9}$ Wnt-jaringan merupakan protein jaringan yang berperan penting dalam perkembangan embrio, proses diferensiasi, dan polaritas sel generasi. ${ }^{10}$

\section{RAMBUT}

Rambut merupakan struktur berkeratin panjang yang berasal dari invaginasi epitel epidermis dan ditemukan di seluruh tubuh kecuali pada telapak tangan, telapak kaki, bibir, glans penis, klitoris, dan labia minor. $^{2,5}$

\section{Struktur rambut}

Rambut terdiri atas sel-sel yang tersusun dalam tiga lapis sepusat yaitu: medula, korteks, dan kutikula (Gambar 1). ${ }^{2}$

\section{Medula}

Medula merupakan bagian tengah rambut yang panjang dan terdiri atas dua sampai tiga lapis sel kubis mengeriput dan menanduk, yang satu sama lain dipisahkan oleh ruang udara. Bulu halus pendek jenis bulu roma, sebagian rambut kepala, dan rambut pirang tidak mempunyai medula. Sel-selnya sering mengandung pigmen. Keratin sel-sel medula termasuk keratin lunak. ${ }^{2,5}$

\section{Korteks}

Korteks merupakan bagian utama rambut dan terdiri atas beberapa lapis sel gepeng, panjang berbentuk gelendong, menanduk membentuk keratin keras. Rambut hitam mengandung pigmen yang teroksidasi. Udara juga terkumpul di dalam ruang antar sel-sel korteks dan mengubah warna rambut. ${ }^{2,5}$

\section{Kutikula}

Kutikula merupakan lapisan terluar, yang terdiri dari selapis sel tipis dan jernih yaitu kutikula. Sel-selnya menanduk dan 
tidak berinti kecuali yang terdapat pada akar rambut. Penampang potongan melintang rambut beragam sesuai dengan ras (Gambar 1). ${ }^{2,5}$

\section{Bentuk rambut}

Terdapat beberapa bentuk rambut, yaitu lurus, berombak, dan keriting. Rambut lurus mempunyai folikel yang lurus dengan penampang bulat. Rambut berombak memperlihatkan gelombang yang besar pada rambut; hal ini disebabkan karena folikelnya melengkung dengan penampang lonjong/oval. Rambut keriting, biasanya membentuk gelombang kecilkecil atau sedang; hal ini disebabkan karena folikel rambut sangat melengkung sedangkan penampangnya gepeng (Gambar 2). ${ }^{2,5}$

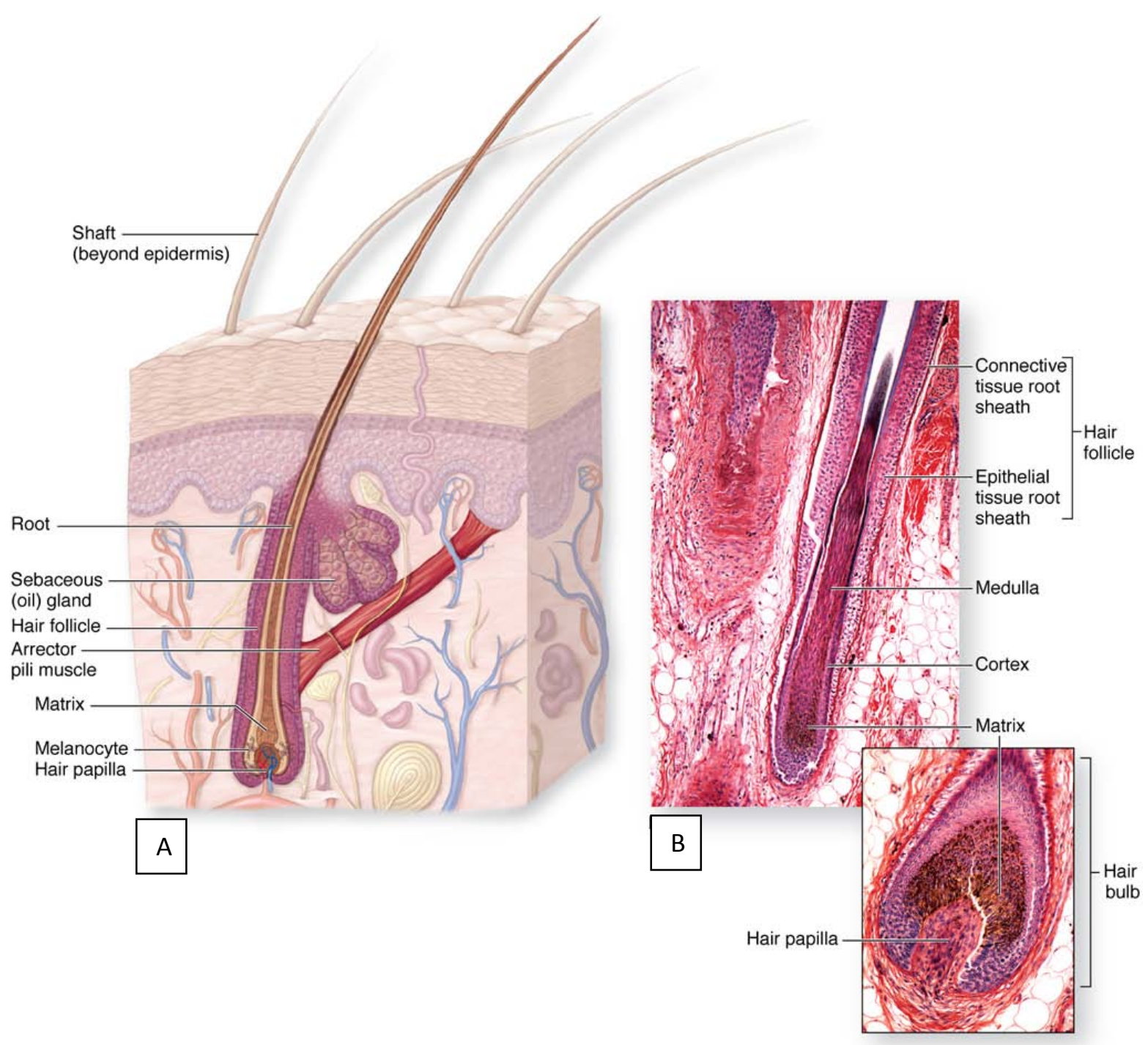

Gambar 1. Rambut. Semua jenis rambut pada tubuh memilliki komposisi dan bentuk folikel rambut yang serupa. Folikel rambut berasal dari epidermis yang meluas ke dalam dermis. Satu atau lebih kelenjar sebasea bersama epidermis yang tumbuh ke dalam disebut unit pilosebaseus. A, Diagram skematik yang memperlihatkan sebagian besar folikel rambut, termasuk otot arektor pili. B, Mikrograf memperlihatkan medula dan korteks pada akar rambut yang terpotong longitudinal serta sarung akar asal epidermis dan sarung jaringan ikat. Sumber: Mescher AL, 2010. ${ }^{2}$ 


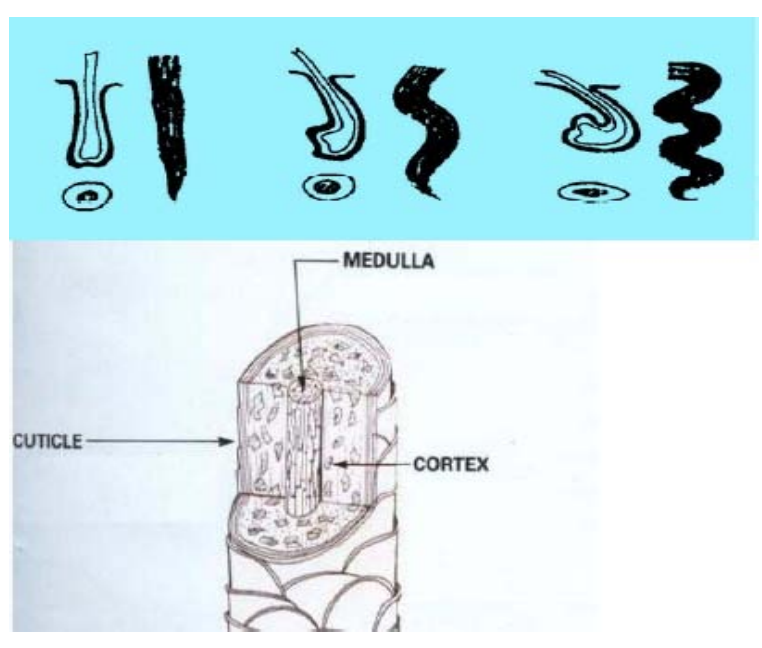

Gambar 2. Bentuk rambut: lurus, berombak, dan keriting. Sumber: Faculty of Biological Sciences, University of Leeds ${ }^{11}$

\section{Jenis folikel}

Berdasarkan ukuran diameter terdapat folikel rambut primer dan sekunder. Folikel primer berukuran besar dan memiliki kelenjar keringat, kelenjar sebasea dan otot arektor pili. Folikel sekunder berukuran lebih kecil, dan mengandung lebih kurang kelenjar keringat dan otot arektor pili (Gambar 3). ${ }^{11,12}$

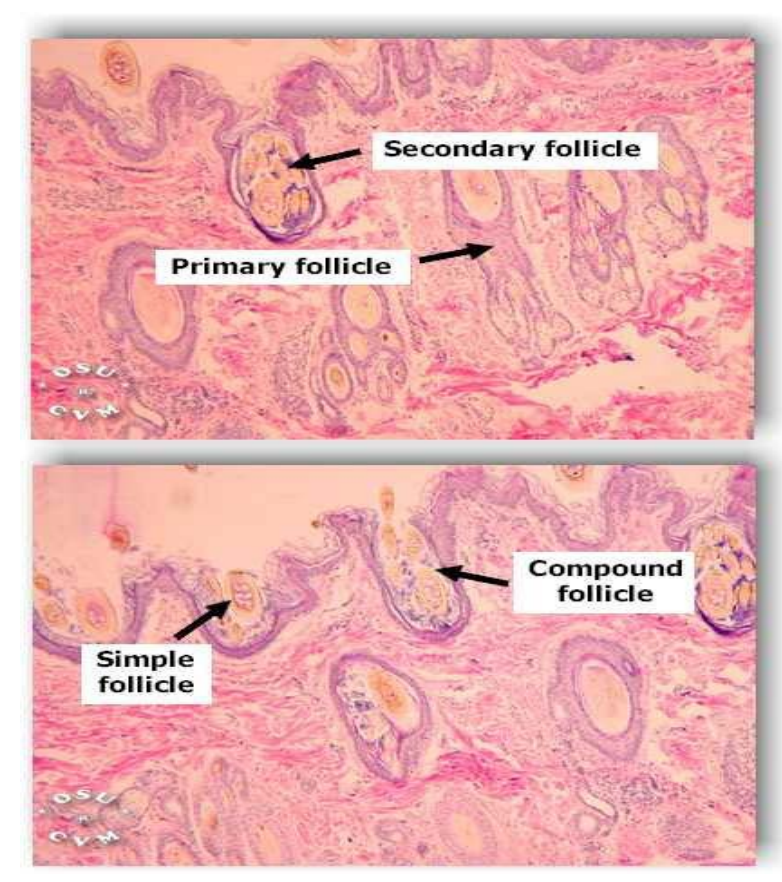

Gambar 3. Jenis folikel primer dan sekunder. Sumber: Ownby CL, 2002. ${ }^{12}$

\section{Pertumbuhan rambut}

Terdapat tiga tahap pada proses tumbuhnya rambut yaitu:

\section{Fase pertumbuhan (anagen)}

Sel-sel matriks melalui mitosis membentuk sel-sel baru yang mendorong sel-sel fase pertumbuhan lebih tua ke atas. Aktivitas ini berlangsung dua sampai lima tahun. Sekitar 85\% dari 100.000 folikel rambut kulit kepala normal mengalami fase pertumbuhan pada satu saat yang sama. ${ }^{2,13}$

\section{Fase istirahat (katagen)}

Masa peralihan dimulai dari penebalan jaringan ikat di sekitar folikel rambut. Bagian tengah akar rambut menyempit sedangkan bagian di bawahnya melebar dan mengalami pertandukan sehingga berbentuk gada (club). Fase ini berlangsung selama dua minggu. Setiap saat, rambut yang mengalami aktivasi pada fase katagen sekitar $1 \% .^{2,13}$

\section{Fase kerontokan (telogen)}

Tahap ini berlangsung tiga sampai empat bulan, dan rambut yang mengalami aktivasi setiap saat $14 \%$. Rambut mengalami kerontokan 50-100 helai setiap harinya, kemudian dimulai lagi dengan fase anagen yang baru, yaitu papila rambut yang mengeriput selama masa katagen akan berkembang kembali. Umbi rambut terbentuk di sekeliling papila rambut dan rambut tumbuh kembali. Dengan kembalinya fase anagen, rambut lama atau rambut gada (clubbed hair) yang sudah berada di bagian atas kandung rambut terdorong lepas oleh tumbuhnya rambut baru (Gambar 4)., 2,13

Fase anagen merupakan bagian paling aktif dari siklus pertumbuhan rambut, dan dapat dibagi menjadi enam tahap yang berbeda. Pembentukan rambut berwarna abu-abu dan teori stres oksidatif berfokus pada fase anagen tahap III dan IV. $^{14}$ Melanosit folikel rambut mencapai puncak pertumbuhan selama tahap III. Melanosit memperbanyak diri di dasar folikel rambut yaitu rongga papila dan mulai transisi ke 
tahap IV yang menandai proses pigmentasi rambut. ${ }^{15}$

Rambut uban tidak tumbuh dengan sendirinya. Batang rambut menerima nutrien dan oksigen dari ujung-ujung pembuluh darah. Kekurangan nutrien dan oksigen mengakibatkan susunan rambut menjadi tidak baik dan mempengaruhi pembentukan melanin rambut sehingga terbentuk rambut uban. ${ }^{16}$

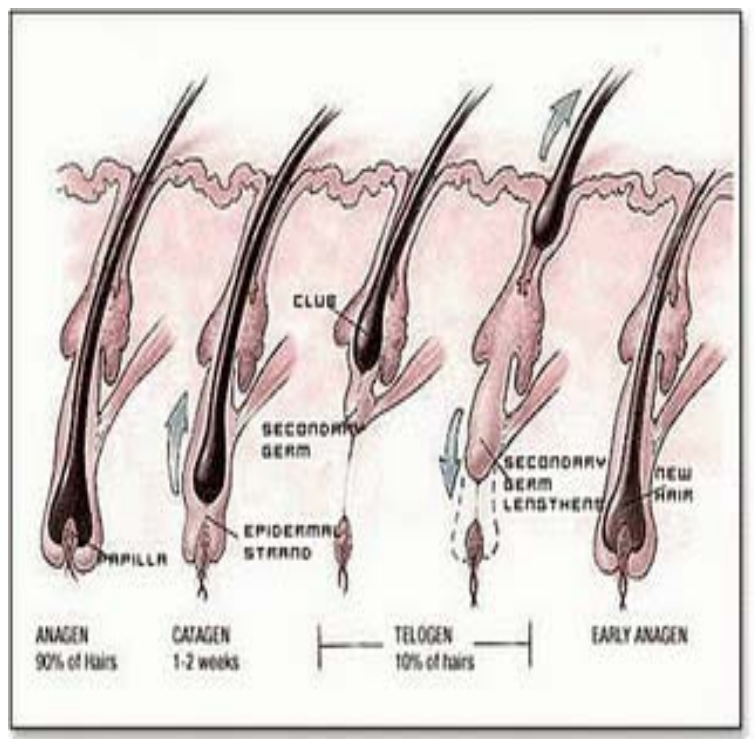

Gambar 4. Fase pertumbuhan rambut. Sumber: Faculty of Biological Sciences, University of Leeds. ${ }^{11}$

\section{MELANOSIT}

Melanosit merupakan target untuk mengendalikan sinyal genetik kulit dan pigmentasi rambut. Melanosit berfungsi untuk menyintesis pigmen melanin yang memberi warna pada kulit dan rambut ${ }^{17}$ sedangkan rambut uban merupakan akibat kekurangan pigmen melanin. ${ }^{18}$

Melanin ialah pigmen warna yang diproduksi oleh melanosit yang terdapat di akar rambut. Seperti halnya warna kulit putih, hitam atau sawo matang, melanosit ini yang menentukan warna rambut seseorang coklat, pirang, atau hitam. ${ }^{17}$

Rambut uban umumnya muncul pada usia 50-an ke atas, karena aktivitas dan kapasitas sel-sel tubuh menurun akibat degenerasi sel (proses penuaan), termasuk melanosit. $^{18,19}$

Munculnya uban dipengaruhi oleh faktor eksternal dan internal. Yang termasuk faktor eksternal ialah antara lain gaya hidup. Perokok aktif cenderung lebih banyak mengalami perubahan warna rambut atau beruban lebih cepat dibandingkan yang tidak merokok. ${ }^{18}$ Faktor lainnya yang dapat menyebabkan uban dini ialah penggunaan minyak dan cat rambut yang tidak hanya mengenai rambut, tetapi juga meresap ke dalam pori-pori kulit kepala. Zat-zat kimia yang terkandung dalam minyak dan cat rambut memengaruhi kesehatan rambut dan produksi pigmen melanin sehingga mempercepat terjadinya uban. $^{19}$

Sebagai faktor internal yaitu faktor genetik yang merupakan penyebab yang paling umum munculnya uban pada usia muda. Terjadinya uban dini diatur secara genetik; jika orang tua mengalami uban dini, kemungkinan besar hal ini akan menurun pada anak-anaknya. ${ }^{18,19}$

Percobaan pada tikus dapat mengungkap bagaimana jalur sinyal Wnt diaktifkan baik sel induk folikel rambut maupun sel induk melanosit yang bekerja sama untuk menghasilkan pertumbuhan rambut dan warna rambut. Dalam penelitian ini juga ditunjukkan deplesi (inhibisi atau abnormalitas) sinyal Wnt dalam sel-sel induk folikel rambut tidak hanya menghambat pertumbuhan kembali rambut, tapi juga mencegah aktivasi melanosit induk yang diperlukan untuk memroduksi warna rambut. Kurangnya aktivasi Wnt dalam sel induk melanosit menyebabkan rambut mengalami depigmentasi atau berwarna kelabu. ${ }^{20}$ Penelitian tersebut membuka peluang bahwa sinyal Wnt merupakan jalur kunci untuk pengaturan sel induk melanosit dan menunjukkan bagaimana perilaku melanosit berhubungan dengan regenerasi rambut. $^{20}$

\section{MELANIN}

Melanin diproduksi oleh melanosit dalam folikel rambut. Para peneliti menemukan bahwa melanosit dapat bertahan 
dari kerusakan kumulatif selama bertahuntahun, dan akan berakhir pada saat melanosit tidak mampu memroduksi melanin lagi. ${ }^{16}$

Kerusakan DNA dan penumpukan hidrogen peroksida dalam folikel sebagai kemungkinan penyebab dalam menurunnya produksi melanin. Tanpa melanin, rambut baru yang tumbuh tidak memiliki pigmen, yang mengakibatkan rambut tampak berwarna kelabu, putih, atau perak. ${ }^{21}$

Jenis melanin yang paling umum ialah eumelanin dan feomelanin. Eumelanin berwarna coklat hitam yang merupakan polimer dari dihidroksi indol asam karboksilat. Bentuk lain melanin ialah feomelanin berwarna merah-coklat dan merupakan polimer dari benzothiazine. ${ }^{14}$

\section{Eumelanin}

Eumelanin (melanin sejati) memberi warna gelap pada rambut. Pigmen eumelanin biasanya terdapat pada orangorang berwarna kulit gelap seperti Asia, Arab, dan India. ${ }^{22}$

Eumelanin merupakan protein yang mengandung asam amino tirosin. Pembentukan eumelanin membutuhkan enzim tirosinase, yang menggabungkan asam amino tirosin ke molekul dopa dan dopamin. Tirosinase lebih aktif pada orang dewasa dibandingkan pada anak-anak atau remaja, sedangkan pada orang tua enzim ini tidak begitu aktif lagi. Defisiensi tirosin dapat memengaruhi warna rambut manusia. Kurangnya tirosin menyebabkan warna rambut yang seharusnya gelap akan memudar. $^{21}$

Terdapat dua macam warna eumelanin yaitu coklat atau hitam. Rambut dengan konsentrasi melanin hitam tinggi akan memperlihatkan warna hitam, sedangkan rambut dengan konsentrasi melanin coklat tinggi akan memperlihatkan warna coklat. Jika pigmen melanin hitam rendah, warna yang terlihat ialah kelabu atau putih, sedangkan jika pigmen melanin coklat yang rendah, warna yang terlihat kuning (pirang). Melanin coklat lebih stabil dan bertahan lama daripada melanin hitam. ${ }^{21}$

\section{Feomelanin}

Feomelanin berwarna kemerahan atau pirang, tersusun atas asam amino tirosin, dan juga membutuhkan enzim tirosinase. Pigmen itu merupakan produksi dari eumelanin, yang bereaksi dengan asam amino sistein yang mengandung atom sulfur, sehingga warna rambut menjadi kemerahan atau jingga. Semakin banyak interaksi dengan sistein, maka semakin merah warna rambut yang terbentuk. Biasanya rambut merah juga berhubungan dengan penghambatan pembentukan eumelanin. Feomelanin memiliki stabilitas antara melanin coklat dan hitam. ${ }^{21}$

Biasanya rambut putih atau uban muncul pada orang tua karena produksi melanin memang sudah mulai berkurang. Metabolisme untuk memroduksi pigmen mulai melambat, bahkan sampai tidak ada lagi. $^{22}$

\section{Komposisi pigmen pada warna rambut}

Warna rambut yang terlihat (fenotip) tergantung pada perbandingan kadar eumelanin dan feomelanin pada rambut tersebut. Rambut hitam terdiri dari 99\% eumelanin $+1 \%$ feomelanin; rambut coklat/pirang terdiri dari $\leq 95 \%$ eumelanin $+\geq 5 \%$ feomelanin; sedangkan rambut merah terdiri dari $67 \%$ eumelanin $+33 \%$ feomelanin. ${ }^{21}$

\section{Pembentukan pigmen melanin}

Melanin dibentuk oleh melanosit dengan bantuan enzim tirosinase yang berperan penting dalam proses pembentukannya. Oleh kerja enzim tironase, tiroksin diubah menjadi 3,4 dihidroksiferil alanin (DOPA) dan kemudian menjadi dopaquinone, yang kemudian dikonversi melalui beberapa tahap transformasi menjadi melanin. Enzim tirosinase dibentuk dalam ribosom, ditransfer dalam lumen retikulum endoplasma kasar, dan melanosit diakumulasi dalam vesikel yang dibentuk oleh kompleks Golgi. ${ }^{17}$

Terdapat empat tahap pada pembentukan granula melanin yang matang 
(Gambar 5). ${ }^{17}$ Tahap-tahap tersebut secara berurut yaitu: 1) sebuah vesikel dikelilingi oleh membran dan menunjukkan awal proses aktivitas enzim tirosinase dan pembentukan substansi granula halus pada bagian perifernya. Untaian-untaian padat elektron memiliki suatu susunan molekul tirosinase yang rapi pada matrik protein; 2) vesikel (melanosom) berbentuk oval dan bagian dalamnya memperlihatkan filamenfilamen dengan jarak sekitar $10 \mathrm{~nm}$ atau garis lintang dengan jarak sama. Melanin disimpan dalam matriks protein; 3) peningkatan pembentukan melanin membuat struktur halus agak sulit terlihat; dan 4) granula melanin matang dapat dilihat dengan mikroskop cahaya dan melanin ini telah mengisi vesikel secara sempurna.

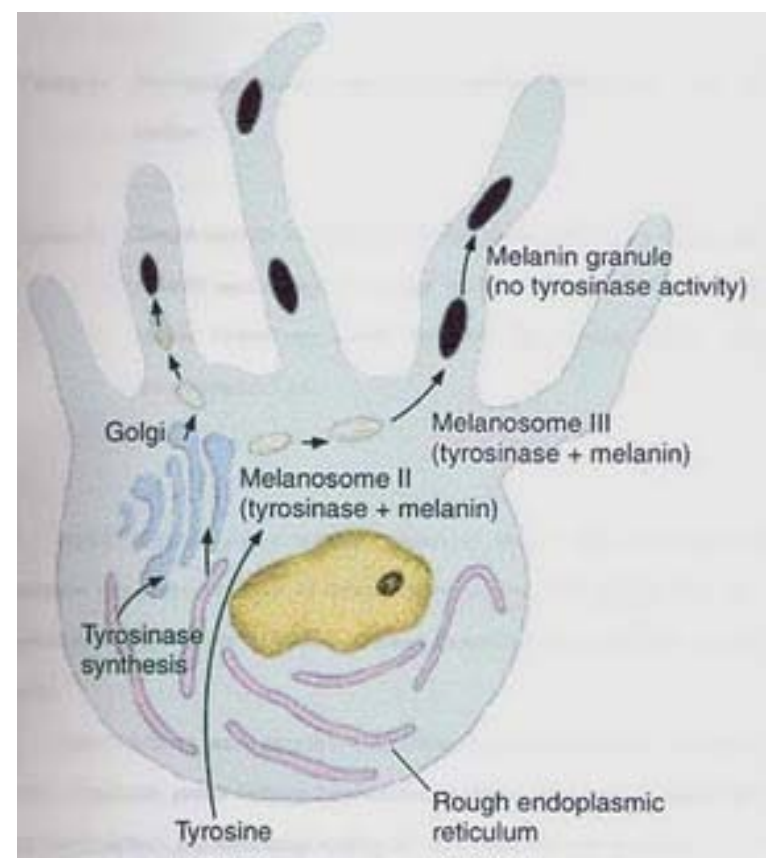

Gambar 7. Diagram melanosit dan ilustrasi gambaran utama melanogenesis. Tirosinase di sintesis dalam retikulum endoplasma kasar dan diakumulasikan dalam vesikel kompleks Golgi. Vesikel bebas sekarang dinamakan melanosom. Sintesis melanin dimulai dalam melanosom tahap II, di mana melanin diakumulasikan dan membentuk melanosom tahap III. Akhirnya struktur ini hilang oleh aktivitas tirosinase dan membentuk granul melanin. Granula melanin bermigrasi ke arah juluran melanosit dan masuk ke dalam keratinosit. ${ }^{17}$
Utrastruktur tidak ada yang terlihat. Granula yang matang berbentuk elips, dengan panjang $1 \mu \mathrm{m}$ dan diameter $0,4 \mu \mathrm{m} .{ }^{14}$

Sebagian kecil rambut tidak tumbuh dan masih dalam tahap istirahat. Seiring dengan berjalannya waktu, rambut tersebut akan menjadi tua dan mulai berubah warna dari hitam menjadi kelabu dan putih. ${ }^{22}$

\section{SIMPULAN}

Rambut uban merupakan kelainan rambut akibat kekurangan pigmen melanin sehingga rambut tampak berwarna putih. Melanosit menyintesis pigmen melanin yang menentukan warna rambut. Aktivitas melanosit terbesar terjadi pada fase anagen saat rambut tumbuh sedangkan pada fase katagen dan telogen pembentukan melanin sudah berhenti. Terjadinya rambut uban dipengaruhi oleh faktor eksternal seperti gaya hidup, merokok, dan zat kimia (minyak rambut, pewarna rambut, dan hairspray) serta faktor internal yaitu genetik.

\section{DAFTAR PUSTAKA}

1. Santoso F. Tampil lebih muda berkat cat penutup uban. Majalah Gaya Hidup Sehat. Oktober 2008 - 03 November 2011;28(31):12.

2. Mescher AL. Junqueira's Basic Histology Text \& Atlas (Twelfth Edition). New York: Mc Graw Hill Medical, 2010.

3. Perawatan rambut. Jurnal Pendidikan Kesejahteraan Keluarga [homepage on the Internet]. Nodate [cited 2011 Apr 15]. Available from: http://file.upi.edu/ Direktori/FPTK/JUR._PEND._KESEJ AHTERAAN_KELUARGA/19590203 1986032-MARLINA/BU_112_Dasar_ Rias/5\%2B6_Perawatan_Rambut.pdf

4. Hegney F. Gray hair causes: Oxidative stress-hydrogen peroxide theory [homepage on the Internet]. Nodate [cited 2011 May 23]. Available from: http://translate.google.com/translate?hl =id\&sl=id\&tl=en\&u=http\%3A\%2F\%2 Fwww.greydefence.com\%2Fblog\%2Fg ray-hair-research-articles\%2Foxidativestress-theory-hydrogen-peroxide-grayhair\%2F. 
5. Leeson ST, Leeson RC, Paparo AA. Buku Ajar Histologi (Edisi Kelima). Jakarta: EGC, 1995; hal.316-8.

6. Hegney F. Gray hair causes: Vitamin B12 and folic acid deficiency theory [homepage on the Internet]. Nodate [cited 2011 Apr 21]. Available from: http://translate.google.com/translate?hl $=\mathrm{id} \& \mathrm{sl}=\mathrm{id} \& \mathrm{tl}=\mathrm{en} \& \mathrm{u}=\mathrm{http} \% 3 \mathrm{~A} \% 2 \mathrm{~F} \% 2$ Fwww.greydefence.com\%2Fblog\%2Fg ray-hair-research-articles\%2Fgray-haircausesvitamin-b12-folic-acid\%2F.

7. Jacoeb ANT. Ada uban. The journey of life [homepage on the Internet]. Nodate [cited 2011 Apr 12]. Available from: http://casadelyndra.multiply.com/journa l/item/8/Ada_ubannnnn

8. Mengenal manusia albino lebih dalam [homepage on the internet]. Nodate [cited 2011 Apr 15]. Available from: http://arunkita.com/article-11-mengenal-manusia-albino-lebih-dalam.html.

9. Hegney F. Teori genetika mulai beruban [homepage on the Internet]. Nodate [cited 2010 Jun 20]. Available from: http://translate.google.co.id/translate?hl =id\&langpair $=$ en\%7Cid\&u=http\%3A\% 2F\%2Fwww.greydefence.com\%2Fblog \%2Fgray-hair-research-articles\%2Fgrayhair-theories-genetics\%2F.

10. Wikipedia Foundation, Inc. Wnt sinyal jalur [homepage on the Internet]. Nodate [cited 2011 Nov 16]. Available from: http://translate.google.co.id/translate?hl=id\&sl=en\&u=http://en.wikipedi a.org/wiki/Wnt_signaling_pathway\&ei =uTLETvHCCMfnrAfv_YX8Cw\&sa= $\mathrm{X} \& \mathrm{oi}=$ translate\&ct $=$ result\&resnum $=1 \&$ ved=0CB8Q7gEwAA\&prev=/search\% 3Fq\%3Ddefinisi\%2Bwnt\%2Bsignaling \%26hl\%3Did\%26client\%3Dfirefoxa\%26hs\%3D9Zo\%26rls\%3Dorg.mozill a:en-US:official\%26biw\%3D1280\%26 bih\%3D663\%26prmd\%3Dimvns.

11. Histology guide. Faculty of Biological Sciences, University of Leeds. Nodate [cited 2011 May 23]. Available from: http://www.histology.leeds.ac.uk/skin/h air.ph.

12. Ownby CL. Histology part 2 index [homepage on the Internet]. 2002 [cited 2011 Apr 18]. Available from: http://instruction.cvhs.okstate.edu/histol ogy/HistologyReference/hrskin.htm.

13. Graham R. Lecture Notes Dermatologi
(Edisi Kedelapan). Jakarta: Erlangga, 2005; p.5-6. [cited 2011 Apr 20]. Available from: http://books.google. co.id/books?id=p2rU5scf5G0C\&pg=P

A24\&dq=histologi+rambut\&hl=id\&ei= 6IbHTtmzHKXqmAWlo4n4Dw\&sa=X \&oi=book_result\&ct=result\&resnum $=9$ \&ved=0CE4Q6AEwCDgK\#v=onepage $\& \mathrm{q}=$ histologi\%20rambut \&f=false

14. Kimia Indonesia [homepage on the internet]. Nodate [cited 2011 Apr 18]. Available from: http://indonesiakimia. blogspot.com/2011/06/melanin.html

15. Tobin DJ, Slominskia A, Bothchkarev V. (1999). Nasib folikel rambut melanosit selama siklus pertumbuhan rambut. J Invest Dermatol [homepage on the Internet]. 1999 [cited 2011 May 9]. Available from: http://translate.google. com/translate?hl=id\&langpair=en|id\&ru $\mathrm{rl}=$ translate.google.co.id\&u=http://ww w.greydefence.com/blog/gray-hairresearch-articles/gray-hair-freeradicals/.

16. Barus IP. Penyebab tumbuhnya rambut uban [homepage on the Internet]. Nodate [cited 2011 Nov 13]. Available from: http://meetdoctor.com/article/ penyebab-tumbuhnya-rambut-uban.

17. Hair color: Why do you have blond, red, brown or black hair and why does it turn gray and white? ISHRS [homepage on the Internet]. Nodate [cited 2006 May 9]. Available from: http://translate. google.co.id/translate?hl=id\&langpair= en|id\&u=http\%3A\%2F\%2Fwww.ishrs. org\%2Farticles\%2Fhair-color.htm.

18. Santoso F. Bila rambut mulai putih [homepage on the Internet]. Nodate [cited 2011 Nov 26]. Available from: http://www.surya.co.id/2011/11/26/bila -rambut-mulai-putih.

19. Winarto. Penyebab rambut uban pada usia muda. Artikel Kesehatan [homepage on the Internet]. Nodate [cited 2011 Mar 30]. Available from: http://www.nabitist.com/penyebab-rambut-uban-padausia-muda.html.

20. Ito M. Why hair turns gray: Communication between hair follicles and melanocyte stem cells key to mystery. Journal Cell [homepage on the Internet]. Nodate [cited 2011 Jun 11]. Available from: http://translate.google. co.id/translate?hl=id\&sl=id\&tl=en\&u= 
S12 Jurnal Biomedik, Volume 4, Nomor 3, Suplemen, November 2012, hlm. S4-12

http\%3A\%2F\%2Fwww.sciencedaily.co $\mathrm{m} \% 2$ Freleases\%2F2011\%2F06\%2F110 614115046.htm.

21. Melanin atau melamin [homepage on the internet]. Nodate [cited 2011 Mon date]. Available from: http://www. scribd.com/doc/52306453/Melanin- atau-melamin.

22. Cegah uban di usia muda. Faculty of Medicine Airlangga University [homepage on the Internet]. Nodate [cited 2010 Jun 03]. Available from: http://www.fk.unair.ac.id/index.php/Fo cus/cegah-uban-di-usia-muda.html. 